\title{
Reduced CSF turnover and decreased ventricular A 342 levels are related
}

\author{
Jean-Marie Serot ${ }^{*}$, Johann Peltier ${ }^{2}$, Antony Fichten ${ }^{2}$, Nelly Ledeme ${ }^{3}$, Anne-Marie Bourgeois ${ }^{3}$, Pierre Jouanny ${ }^{1}$, \\ Patrick Toussaint ${ }^{2}$, Daniel Legars ${ }^{2}$, Olivier Godefroy ${ }^{4}$ and Jean-Claude Mazière ${ }^{3}$
}

\begin{abstract}
Background: The appearance of $A \beta 42$ peptide deposits is admitted to be a key event in the pathogenesis of Alzheimer's disease, although amyloid deposits also occur in aged non-demented subjects. $A \beta 42$ is a degradation product of the amyloid protein precursor (APP). It can be catabolized by several enzymes, reabsorbed by capillaries or cleared into cerebrospinal fluid (CSF). The possible involvement of a decrease in CSF turnover in A4 32 deposit formation is up to now poorly known. We therefore investigated a possible relationship between a reduced CSF turnover and the CSF levels of the A4 32 peptide.

To this aim, CSF of 31 patients with decreased CSF turnover were studied. These patients presented chronic hydrocephalus communicating or obstructive, which required surgery (ventriculostomy or ventriculo-peritoneal shunt). Nine subjects had idiopathic normal pressure hydrocephalus (iNPH), and the other 22 chronic hydrocephalus from other origins (oCH).

The A 342 peptide concentration was measured by an ELISA test in 31 ventricular CSF samples and in 5 lumbar CSF samples from patients with communicating hydrocephalus.

Results: The 5 patients with lumbar CSF analysis had similar levels of lumbar and ventricular Aß42. A significant reduction in $A \beta 42$ ventricular levels was observed in 24 / 31 patients with hydrocephalus. The values were lower than $300 \mathrm{pg} / \mathrm{ml}$ in 5 out of 9 subjects with iNPH, and in 15 out of 22 subjects with oCH.

Conclusion: The decrease of CSF A 342 seems to occur independently of the surgical hydrocephalus aetiology. This suggests that a CSF reduced turnover may play an important role in the decrease of CSF A 42 concentration.
\end{abstract}

\section{Background}

Alzheimer's disease (AD) is characterized by the presence of diffuse and senile dense-core plaques. Senile plaques may also be seen in non-demented elderly patients. According to the " amyloid theory ", the appearance of $\mathrm{A} \beta 42$ deposits is considered as the crucial event in the evolution of $\mathrm{AD}$ [1].

A $\beta 42$ can be reabsorbed by capillaries via specific receptors, the most charaterized being LRP-1 [2], degraded by several enzymatic pathways or cleared into cerebrospinal fluid (CSF) [3]. In AD patients, $\mathrm{A} \beta 42$ production is similar to that of cognitively normal controls, but its clearance is impaired [4]. The CSF turnover is defined by the volume of CSF produced in 24 hours divided by the volume of the CSF space. It can be

\footnotetext{
* Correspondence: serot.jean-marie@chu-amiens.fr

'Department of Gerontology, CHU Amiens, France Full list of author information is available at the end of the article
}

estimated to 4 volumes per day for healthy young adults [5]. The consequences of decreased CSF turnover on the clearance of $A \beta 42$ were still unknown.

In vitro, $A \beta 42$ monomers, incubated into CSF, build spontaneously oligomers and then fibrils; these phenomena are time-dependant [6,7]. Experimentally, it has been shown that brain amyloid deposits accumulate in rats with kaolin-induced hydrocephalus [2]. In this model, immunochemistry shows an accumulation of A 342 without significant increase in APP expression. This is associated to an increase in p-tau and a loss of dendritic staining. Altered CSF turnover seems to affect A $\beta 42$ clearance and to favour amyloid cerebral deposit formation [8].

Several human types of chronic hydrocephalus with altered CSF turnover are known, such as idiopathic Normal Pressure Hydrocephalus (iNPH), and those following meningeal haemorraghe or related to surgery for
C Biomed Central 
Sylvius acqueduct stenosis, or brain tumors. iNPH is a rare disease (about 1 case for 200000 people), described in 1965, and characterized by a clinical triad of mental alteration, gait disturbance and sphincter dysfunction [9]. In this affection, ventricular dilatation has also been described, with a normal pressure of lumbar CSF, a perturbation of CSF resorption, and a correlative reduction in CSF turnover to less than 1.5 volume per day instead of 4 volumes as seen in young controls [5]. In AD, CSF turnover is also reduced and can be estimated to less than 1.5 volume per day $[5,10]$.

In order to investigate a possible involvement of a decrease in CSF turn-over on A $\beta 42$ clearance, we studied the ventricular levels of this peptide in patients suffering from chronic hydrocephalus, which required surgery (ventriculostomy or ventriculo-peritoneal shunt). We compared lumbar and ventricular CSF levels in some patients with communicating hydrocephalus, we found ventricular levels are decreased in iNPH and similar to those measured in patients suffering from chronic hydrocephalus, communicating or obstructive.

\section{Methods}

The prospective study was performed on a panel of 31 consecutive patients (men: 17 , women: 14), aged from 28 to 86 years (mean age $64.9 \pm 15.5$ years; median 68 years). All of them were affected with chronic hydrocephalus from various aetiologies, which required either a ventriculostomy or a ventriculo-peritoneal shunt. In Phase Contrast MRI, all the patients had ventricular dilatation and periventricular edema due to transependymal resorption of CSF; the patients with communicating hydrocephalus were also characterized by hyperdynamic aqueductal CSF flow [11].

The experimental protocol was the following: during the surgery, 3-4 $\mathrm{cm}^{3}$ of CSF were aspired, as usual, in order to check the position or the functionality of the shunt. After sampling for cyto-bacteriological analysis, residual CSF was immediately aliquoted in polypropylene tubes placed on ice, and transported to the Biochemistry Laboratory, where it was centrifuged at 4000 $\times \mathrm{g}$ for $10 \mathrm{~min}$., then stored at $-80^{\circ} \mathrm{C}$. This study was achieved according to the French bioethic rules for clinical studies on tailing samples. All the patients gave first their agreement for this protocol.

The respective diagnoses for these patients were: 9 iNPH, and 22 chronic hydrocephalus from other origins $(\mathrm{oCH}): 3$ related to a meningitis or a meningeal haemorrhage, 4 due to stenosis of the Sylvius aqueduct, 10 from benign or malignant tumor origin, 2 following a meningioma surgery, 2 due to a Arnold-Chiari syndrome or a neonatal hydrocephaly and one secondary to the rupture of a dermoid cyst. Five out of these patients (3 with iNPH and 2 with hydrocephalus post subarachnoidal haemorraghe, all older than 65 years) also benefited of a prior subtractive lumbar tap.

The concentrations of $A \beta 42$ were measured using a commercial ELISA test (Innotest $\beta$-amyloid [1-42] from Innogenetics, Ghent, Belgium). With this method, the intra-assay variability coefficient is less than $6 \%$. The range for the titration zone is $125-2000 \mathrm{pg} / \mathrm{ml}$. CSF lumbar $A \beta 42$ levels higher than $500 \mathrm{pg} / \mathrm{ml}$ are considered as normal [12].

\section{Statistics}

Ventricular $\mathrm{A} \beta 42$ values in the two groups (iNPH, oCH) were compared using the Student' $t$ test corrected for unequal variance. Correlations between values of $\mathrm{A} \beta 42$ measured in lumbar and ventricular CSF, were analyzed using the Pearson's test. $\mathrm{P}<0.05$ were considered as significant.

\section{Results}

There was no correlation between A $\beta 42$ levels and age. In the 5 patients with lumbar CSF analysis, lumbar and ventricular A $\beta 42$ levels (respectively $415.6 \pm 180.8 \mathrm{pg} / \mathrm{ml}$ and $378.4 \pm 189 \mathrm{pg} / \mathrm{ml}$; $\mathrm{p}>0.05$ ) were found similar and highly correlated $(\mathrm{r}=0.99$; Figure 1$)$. Based on this fact, A $\beta 42$ ventricular values lower than $500 \mathrm{pg} / \mathrm{ml}$ were considered as reduced. This is the case for $24 / 31$ patients (77\%), with values under $300 \mathrm{pg} / \mathrm{ml}$ in 20 patients (64\%) including 5 out of $9 \mathrm{iNPH}(55 \%)$ and 15 out of $22 \mathrm{oCH}$ (68\%; figure 2).

It can also be observed in Figure 2 that no significant difference was found between the iNPH and $\mathrm{oCH}$

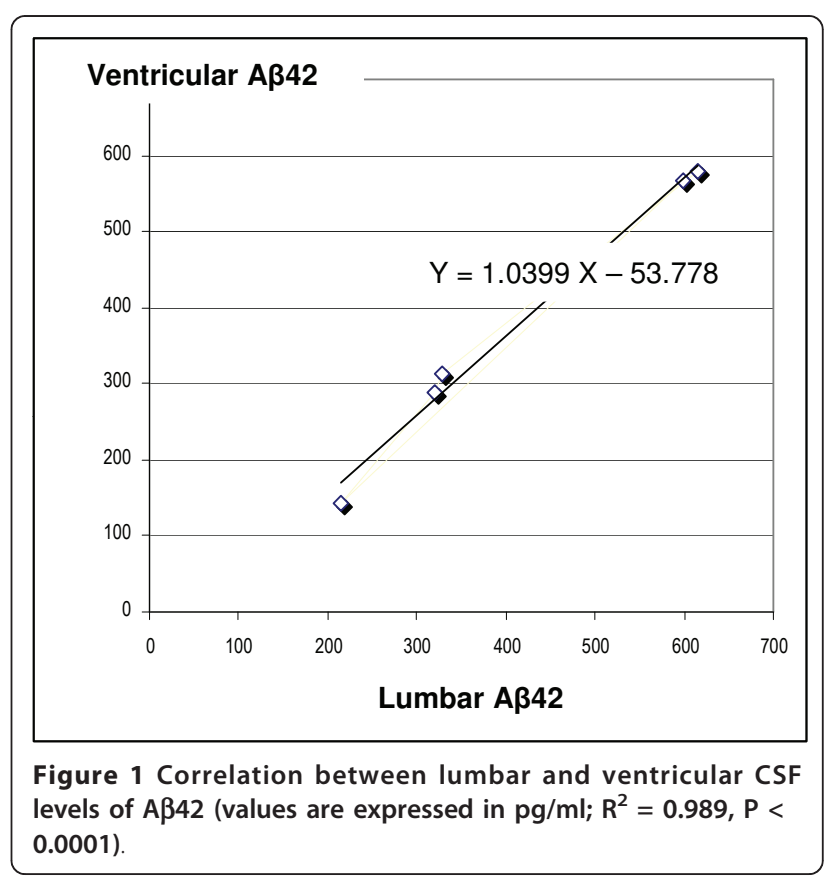




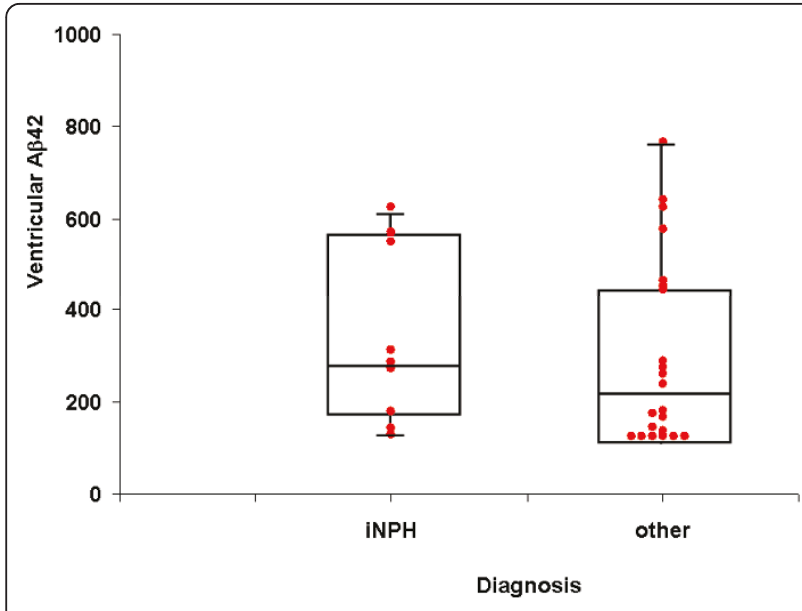

Figure 2 Comparison of ventricular $A \beta 42$ levels between iNPH and other hydrocephalus. The space between 2 horizontal lines is the interquartile range. The boxes represent the $25^{\text {th }}, 50^{\text {th }}$ and $75^{\text {th }}$ percentiles (values are expressed in $\mathrm{pg} / \mathrm{ml}$ ).

groups for ventricular $A \beta 42$ levels (respectively $297.1 \pm$ $343.3 \mathrm{pg} / \mathrm{ml}$ and $206.7 \pm 194.8 \mathrm{pg} / \mathrm{ml}, \mathrm{p}>0.2$; median values 286 and $211 \mathrm{pg} / \mathrm{ml})$.

\section{Discussion}

This work shows that ventricular and lumbar levels of A $\beta 42$ are closely related in communicating hydrocephalus; they are low in iNPH, and comparable to those of other surgical hydrocephalus.

The main limit of this study is that, for ethic reasons, we cannot compare the obtained data to the concentrations existing in "normal" subjects. CSF is a transport medium for numerous molecules (nutriments, growing factors, terminal products of brain cell metabolism). The ventricular and lumbar protein concentrations are often different, depending upon their origin. Indeed, brain proteins are considered to generally exhibit a higher level in intraventricular CSF, whereas blood proteins are more concentrated in lumbar CSF $[13,14]$. However, there are many exceptions; for example, concentrations of transthyretin, a protein synthesized by choroid plexus, are nearly the same in ventricular and lumbar CSF [15].

There are no available reference values well established for $A \beta 42$ ventricular levels in healthy individuals. Therefore, we measured $A \beta 42$ levels in lumbar and ventricular CSF of 5 patients with chronic communicating hydrocephalus and we found that ventricular and lumbar $A \beta 42$ values are not significantly different. Despite the small sample size, this fact suggests the ventricular CSF $A \beta 42$ concentrations measured in this study seem to be relevant for a comparison with those existing in lumbar CSF of control subjects.

In iNPH, several studies [16-19] demonstrated that the lumbar $A \beta 42$ levels are lowered. Our results are in good agreement with these previous data: more than $75 \%$ of the studied patients, whatever the aetiology of the hydrocephalus, exhibit reduced $A \beta 42$ levels in their ventricular CSF. The fact that the ventricular A $\beta 42$ levels were similar iNPH and oCH suggests some similarities in the pathophysiological process despite the existing differences in CSF dynamics and aetiologies. The same findings were reported for other proteins (neurofilament light protein, tau, sulfatide, vasoactive intestinal peptide and neuropeptide Y) in case of iNPH and aqueductal stenosis [20]. Several hypotheses could explain this decrease of $A \beta 42$ levels.

Several hypothesis might be put forward to explain the decrease in $A \beta 42$ levels. First, oligomer formation, favoured by the altered CSF turnover in NPH, could partially mask the antigenic sites of the peptide, especially the C-terminal part, which is hidden inside the hydrophobic core of the aggregate. This therefore could lead to an underestimation of the $A \beta 42$ levels when using an ELISA technique [21]. Second, A $\beta 42$ glycation could contribute to an underestimation of the protein concentration by ELISA. Indeed, the CSF glucose concentration is relatively high (about $0.5 \mathrm{~g} / \mathrm{l}$ ), and CSF stasis promotes Amadori products formation [22], which could also mask some antigenic sites of the peptide. Third, a reduced production of $A \beta 42$ could be suspected, as described in Creutzfeldt-Jacob's disease. In this affection, there are no $A \beta 42$ deposits and CSF A $\beta 42$ levels are significantly reduced [23], this probably due to the inhibition of $\beta$-secretase cleavage by $\operatorname{PrP}(C)$ [24].

However, an intra-cerebral sequestration of amyloid protein most likely occurs. Strozyk et al, investigating the relationship between amyloid neuropathology and post-mortem CSF A $\beta 42$ levels in an autopsy sample of 155 patients with dementia found that a high number of plaques is associated with reduced levels of ventricular A $\beta 42$ [25].

The « B compound of Pittsburgh » (PIB), a thioflavine derivative, which is a ligand of $A \beta 42$, is able, after i.v. injection, to cross the blood brain barrier and bind to A $\beta$ peptides. Molecular neuroimaging allows to detect amyloid pathology in vivo using PET scanning with PIB [26]. Several authors $[27,28]$ using the PIB PET scanning, demonstrated, in patients with Alzheimer disease, that $A \beta 42$ lumbar levels are lowered and inversely correlated to the $A \beta$ load of brain. With the same technique, Leinonen et al [29] demonstrated the occurrence of amyloid deposits in 5/10 patients with iNPH, and cerebral biopsies performed during shunt surgery confirmed the existence of amyloid deposits in these patients. In a large follow-up study of NPH, idiopathic or secondary, Leinonen et al [30] also showed, on small cortical brain biopsies obtained during surgical treatment, that 186/ 433 (43\%) patients displayed A $\beta 42$ deposits. These lesions of $\mathrm{AD}$ are more frequent among older subjects 
with iNPH [31], which could be explained partially by a reduced transport via LRP-I $[2,32]$ and lower activities of some enzymes involved in the catabolism of the A $\beta 42$ peptide [33]; this suggests an increasing role of the CSF turnover in $A \beta 42$ clearance during aging.

It is interesting to note, based on data derived from the ADNI database, an inverse correlation between ventricular size and CSF A 42 levels is observed in controls, MCI and $\mathrm{AD}$, which also supports the hypothesis that the CSF turnover could play an important role in the regulation of the CSF A $\beta 42$ peptide concentration [34].

\section{Conclusion}

Our study shows that ventricular and lumbar levels of $A \beta 42$ are not significantly different in surgical communicating hydrocephalus. Patients with iNPH exhibit a frequent decrease in ventricular CSF A 42 peptide levels, which is in good agreement with decreased lumbar levels previously described. This is consistent with an intra-cerebral sequestration of the peptide resulting from the reduced CSF turnover. Similarly, patients with surgical chronic hydrocephalus of other origins show an impairment of CSF turnover and also exhibit a decrease in $A \beta 42$ ventricular levels. Thus, the decline in CSF $A \beta 42$ concentration is not specific of iNPH and seems independent of the surgical hydrocephalus aetiology. This study suggests that the reduced CSF turnover is a key event in the decrease of $A \beta 42$.

\section{Abbreviations}

CSF: cerebrospinal fluid; iNPH: idiopathic normal pressure hydrocephalus: $\mathrm{OCH}$ : chronic hydrocephalus of other origins; PIB: B compound of Pittsburgh

\section{Acknowledgements}

this study was supported by a grant from the CHU d'Amiens, Université de Picardie Jules Verne, Amiens, France.

\section{Author details}

${ }^{1}$ Department of Gerontology, CHU Amiens, France. ${ }^{2}$ Department of Neurosurgery, CHU Amiens, France. ${ }^{3}$ Department of Biochemistry, INSERM ERI-12, CHU Amiens, France. ${ }^{4}$ Department of Neurology, CHU Amiens, France.

\section{Authors' contributions}

JMS conceived the study, led this project and drafted the manuscript with PJ and JCM. JP, AF, PT, DL, OG, and JMS selected patients. JP, AF, PT and DL removed CSF during surgery. NL, AMB, JCM performed assays. OG performed the statistical analysis. All authors read and approved the final manuscript. All the authors contributed equally to this work.

\section{Competing interests}

The authors declare that they have no competing interests.

Received: 30 January 2011 Accepted: 13 May 2011

Published: 13 May 2011

\section{References}

1. Hardy J, Selkoe DJ: The amyloid hypothesis of Alzheimer's disease: progress and problems on the road to therapeutics. Science 2002, 297:353-356.
2. Klinge PM, Samii A, Niescken S, Brinker T, Silverberg GD: Brain amyloid accumulates in aged rats with kaolin-induced hydrocephalus. Neuroreport 2006, 24:657-660.

3. Cirrito JR, May PC, O'Dell MA, Taylor JW, Parsadanian M, Cramer JW, Audia JE, Nissen JS, Bales KR, Paul SM, DeMattos RB, Holtzman DM: In vivo assessment of brain interstitial fluid with microdialysis reveals plaqueassociated changes in amyloid-beta metabolism and half-life. J Neurosci 2003, 23:8844-8853.

4. Mawuenyega KG, Sigurdson W, Ovod V, Munsell L, Kasten T, Morris JC, Yarasheski KE, Bateman RJ: Decreased clearance of CNS beta-amyloid in Alzheimer's disease. Science 2010, 330:1774.

5. Silverberg GD, Mayo M, Saul T, Rubenstein E, McGuire D: Alzheimer's disease, normal-pressure hydrocephalus, and senescent changes in CSF circulatory physiology: a hypothesis. Lancet Neurology 2003, 2:506-511.

6. Ono K, Noguchi M, Matsumoto Y, Yanase D, Iwasa K, Naiki H, Yamada M: Cerebrospinal fluid of Alzheimer patients promotes beta-amyloid fibril formation in vitro. Neurobiol Dis 2005, 20:233-240.

7. Ikeda T, Ono K, Elashoff D, Condron MM, Noguchi-Shinohara M, Yoshita M, Teplow DB, Yamada M: Cerebrospinal Fluid from Alzheimer's disease patients promotes amyloid beta-protein oligomerization. J Alzheimers Dis 2010, 21:81-86.

8. Silverberg GD, Miller M, Machan JT, Johanson CE, Caralopoulos IN, Pascale CL, Heile A, Klinge PM: Amyloid and tau accumulate in the brains of aged hydrocephalic rats. Brain Res 2010, 1317:286-296.

9. Adams RD, Fisher CM, Hakim S, Ojemann RG, Sweet WH: Symptomatic occult hydrocephalus with"normal" cerebrospinal fluid pressure. A treatable syndrome. N Engl J Med 1965, 273:1117-1126.

10. May C, Kaye JA, Atack JR, Schapiro MB, Friedland RP, Rapoport SI: Cerebrospinal fluid production is reduced in healthy aging. Neurology 1990, 40:500-503.

11. Baledent O, Gondry-Jouet C, Stoquart-Elsankari S, Bouzerar R, Le Gars D, Meyer ME: Value of phase contrast magnetic resonance imaging for investigation of cerebral hydrodynamics. J Neuroradiol 2006, 33:292-303.

12. Sjögren $M$, Vanderstichele $H$, Agren $H$, Zachrisson $O$, Edsbagge $M$ Wikkelsø C, Skoog I, Wallin A, Wahlund LO, Marcusson J, Nägga K, Andreasen N, Davidsson P, Vanmechelen E, Blennow K: Tau and Aß42 in cerebrospinal fluid from healthy adults 21-93 years of age: establishment of reference values. Clin Chem 2001, 47:1776-1781.

13. Reiber $\mathrm{H}$ : Proteins in cerebrospinal fluid and blood: barriers, CSF flow rate and source-related dynamics. Restor Neurol Neurosci 2003, 21:79-96.

14. Johanson CE: Ventricles and cerebrospinal fluid. In Neuroscience in Medicine. Edited by: P. Michael Conn. Philadelphia, JB Lippincott Company; 1995:171-196

15. Ingenbleek $Y$, Young V: Transthyretin prealbumin in health and disease: nutritional implications. Annu Rev Nutr 1994, 14:495-533.

16. Lins $H$, Wichart I, Bancher C, Wallesch CW, Jellinger KA, Rösler N: Immunoreactivities of amyloid beta peptide((1-42)) and total tau protein in lumbar cerebrospinal fluid of patients with normal pressure hydrocephalus. J Neural Transm 2004, 111:273-280.

17. Tarnaris A, Watkins LD, Kitchen ND: Biomarkers in chronic adult hydrocephalus. Cerebrospinal Fluid Res 2006, 3:11.

18. Agren-Wilsson A, Lekman A, Sjöberg W, Rosengren L, Blennow K Bergenheim AT, Malm J: CSF biomarkers in the evaluation of idiopathic normal pressure hydrocephalus. Acta Neurol Scand 2007, 116:333-339.

19. Kapaki EN, Paraskevas GP, Tzerakis NG, Sfagos C, Seretis A, Kararizou E, Vassilopoulos D: Cerebrospinal fluid tau, phospho-tau181 and betaamyloid1-42 in idiopathic normal pressure hydrocephalus: a discrimination from Alzheimer's disease. Eur J Neurol 2007, 14:168-177.

20. Tisell M, Tullberg M, Mansson JE, Fredman P, Blennow K, Wikkelsø C: Differences in cerebrospinal fluids dynamics do not affect the levels of biochemical markers in ventricular CSF from patients with aqueductal stenosis and idiopathic normal pressure hydrocephalus. Eur J Neurol 2004, 11:17-23.

21. Stenh $C$, Englund $H$, Lord A, Johansson AS, Almeida CG, Gellerfors $P$, Grenngard P, Gouras GK, Lannfelt L, Nilsson LNG: Amyloid- $\beta$ oligomers are inefficienly measured by enzyme-linked immunosorbent assay. Ann Neurol 2005, 58:147-150.

22. Shuvaev W, Laffont I, Serot JM, Fujii J, Taniguchi N, Siest G: Increased protein glycation in cerebrospinal fluid of Alzheimer's disease patients. Neurobiol Aging 2001, 22:397-402. 
23. Otto M, Esselmann H, Schulz-Shaeffer W, Neumann M, Schröter A, Ratzka P, Cepek L, Zerr I, Steinacker P, Windl O, Kornhuber J, Kretzschmar HA, Poser S, Wiltfang J: Decreased beta-amyloid1-42 in cerebrospinal fluid of patients with Creutzfeldt-Jakob disease. Neurology 2000, 54:1099-1102.

24. Parkin ET, Watt NT, Hussain I, Eckman EA, Eckman CB, Manson JC, Baybutt HN, Turner AJ, Hooper NM: Cellular prion protein regulates betasecretase cleavage of the Alzheimer's amyloid precursor protein. Proc Natl Acad Sci USA 2007, 104:11062-11067.

25. Strozyk D, Blennow K, White LR, Launer LJ: CSF Abeta 42 levels correlate with amyloid-neuropathology in a population-based autopsy study. Neurology 2003, 60:652-656.

26. Klunk WE, Engler H, Nordberg A, Wang Y, Blomqvist G, Holt DP, Bergström M, Savitcheva I, Huang GF, Estrada S, Ausén B, Debnath ML, Barletta J, Price JC, Sandell J, Lopresti BJ, Wall A, Koivisto P, Antoni G, Mathis CA, Långström B: Imaging brain amyloid in Alzheimer's disease with Pittsburgh Compound-B. Ann Neurol 2004, 55:306-319.

27. Fagan AM, Mintun MA, Mach RH, Lee SY, Dence CS, Shah AR, LaRossa GN, Spinner ML, Klunk WE, Mathis CA, DeKosky ST, Morris JC, Holtzman DM: Inverse relation between in vivo amyloid imaging load and cerebrospinal fluid Abeta42 in humans. Ann Neurol 2006, 59:512-519.

28. Grimmer T, Riemenschneider M, Förstl H, Henriksen G, Klunk WE, Mathis CA, Shiga T, Wester HJ, Kurz A, Drzezga A: Beta amyloid in Alzheimer's disease: increased deposition in brain is reflected in reduced concentration in cerebrospinal fluid. Biol Psychiatry 2009, 65:927-934.

29. Leinonen V, Alafuzoff I, Aalto S, Suotunen T, Savolainen S, Någren K, Tapiola T, Pirttilä T, Rinne J, Jääskeläinen JE, Soininen H, Rinne JO: Assessment of beta-amyloid in a frontal cortical brain biopsy specimen and by positron emission tomography with carbon 11-labeled Pittsburgh Compound B. Arch Neurol 2008, 65:1304-1309.

30. Leinonen V, Koivisto AM, Savolainen S, Rummukainen J, Tamminen JN Tillgren T, Vainikka S, Pyykkö OT, Mölsä J, Fraunberg M, Pirttilä T, Jääskeläinen JE, Soininen $\mathrm{H}$, Rinne J, Alafuzoff I: Amyloid and tau proteins in cortical brain biopsy and Alzheimer's disease. Ann Neurol 2010, 68:446-53.

31. Golomb J, Wisoff J, Miller DC, Boksay I, Kluger A, Weiner H, Salton J, Graves W: Alzheimer's disease comorbidity in normal pressure hydrocephalus: prevalence and shunt response. J Neurol Neurosurg Psychiatry 2000, 68:778-781.

32. Silverberg GD, Messier AA, Miller MC, Machan JT, Majmudar SS, Stopa EG, Donahue JE, Johanson CE: Amyloid efflux transporter at the blood brain barrier declines in normal aging. I Neuropathol Exp Neurol 2010, 69:1034-1043.

33. Hellström-Lindahl E, Ravid R, Nordberg A: Age-dependent decline of neprilysin in Alzheimer's disease and normal brain: inverse correlation with A beta levels. Neurobiol Aging 2008, 29:210-221.

34. Ott BR, Cohen RA, Gongvatana A, Okonkwo OC, Johanson CE, Stopa EG, Donahue JE, Silverberg GD: Alzheimer's Disease Neuroimaging Initiative: Brain ventricular volume and cerebrospinal fluid biomarkers of Alzheimer's disease. J Alzheimers Dis 2010, 20:647-657.

doi:10.1186/1471-2202-12-42

Cite this article as: Serot et al: Reduced CSF turnover and decreased ventricular Aß42 levels are related. BMC Neuroscience 2011 12:42.

\section{Submit your next manuscript to BioMed Central and take full advantage of:}

- Convenient online submission

- Thorough peer review

- No space constraints or color figure charges

- Immediate publication on acceptance

- Inclusion in PubMed, CAS, Scopus and Google Scholar

- Research which is freely available for redistribution

Submit your manuscript at www.biomedcentral.com/submit
Biomed Central 